\title{
Constraints Faced by Agripreneurs in Adopting KAU (Kerala Agricultural University) Technology
}

\author{
Raju Parashuram Naik ${ }^{1}$ and S. Helen ${ }^{2}$
}

\begin{abstract}
A study was conducted with the objective of studying the constraints faced by agripreneurs in adopting KAU (Kerala Agricultural University) technology. A sample of 100 respondents who had adopted KAU technology were selected using simple random sampling technique. The study revealed that lack of adequate money for day-to-day expenses was the most important financial constraint faced by the agripreneurs, followed by lack of market information. Non-availability of input materials and high labour cost were the major production and labour constraints and multiple roles was the major personal constraint faced by the agripreneurs.
\end{abstract}

Keywords : Agripreneurs; Constraints; Kerala Agricultural University; Technology

\section{INTRODUCTION}

A shift from farming to agribusiness is an important pathway to rejuvenate Indian agriculture and to make more appealing and profitable venture. Agripreneurship have the potential to add to a scope of social and economic advancement, for example, income generation, employment creation, poverty reduction and development in health, nutrition and overall food security in the national economy.

Agripreneurship is defined as "generally, sustainable, community-oriented, directly-marketed agriculture. Sustainable agriculture denotes a holistic, system oriented approach to farming that focuses on the interrelationships of social, economic, and environmental processes" (Nagalakshmi and
Sudhakar, 2013). Agricultural businesses are always coupled with inherent ambiguity associated with agricultural production. Some significant sources of uncertainty in agribusiness include production risk, price risk, financial risk and changes in government programmes.

In India, $52 \%$ of the total land is cultivable as against $11 \%$ in the world (Uplaonkar and Biradar, 2015). Large population of India is dependent on agriculture for their source of revenue. But Indian agriculture is low in productivity with large number of disguised unemployment. But it is clear that there is a great scope for entrepreneurship in agriculture and this potential can be tapped only by effective

1. P.G. Scholar and 2. Professor, Communication Centre, Kerala Agricultural University, Mannuthy-680 651 , Thrissur, Kerala, India. 
management of different components by an individual with risk bearing capacityand a quest for latest knowledge in agriculture sector to prove as right agripreneurs. Agripreneurship is an employment strategy that can lead to economic self-sufficiency of rural people. In this direction, KAU (Kerala Agricultural University) Kerala has taken earnest and concerted effort to consolidate, showcase and disseminate the various technologies generated suitable for entrepreneurship and skill development. Hence it was felt appropriate to study the constraints faced by the agripreneurs in adopting KAU technologies.

\section{METHODOLOGY}

The present study was conducted in Central zone of Kerala. The list of clients who had adopted KAU technologies were collected from the extension centres of Kerala Agricultural University viz., Krishi Vigyan Kendra, Communication Centre and Central
Training Institute of Thrissur district during 2014 and 2015. One hundred clients who had adopted KAU technologies were selected using simple random sampling technique to form the sample.

Constraints faced by the agripreneurs were classified under financial, marketing, production and labour and personal constraints. It was analyzed using the index method followed by Aiswarya (2016) with suitable modifications. Agripreneurs were asked to rate the constraints on a three point continuum scale. The response of the agripreneurs were assigned score of 3,2 and 1 indicating 'More serious', 'Serious' and 'Less serious' respectively. The total score of each constraint was calculated by summing up the values obtained and index was calculated for consolidating and comparing the seriousness of the problems. The following formula was used for calculating the index of each statement and composite index for all the classified constraints:

\section{Index of each statement $=\quad$ Total score for each statment \\ Maximum score of the statement

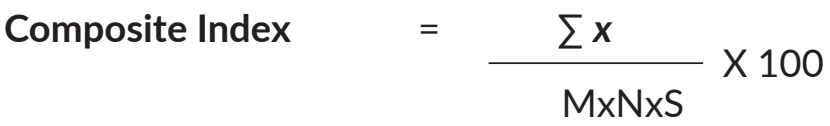

Where, $\Sigma x=$ sum of total scores of all statements (Sum of frequencies multiplied by weight)

$M=$ Maximum score

$\mathrm{N}=$ Number of respondents

$S=$ Number of statements

\section{FINDINGS AND DISCUSSION}

Constraints faced by the agripreneurs were classified under financial, marketing, production and labour and personal constraints and are presented here. 
Table 1

Financial Constraints Faced by Agripreneurs

\begin{tabular}{|c|l|r|r|r|r|r|}
\hline \multicolumn{1}{c|}{$\begin{array}{c}\text { Sl. } \\
\text { No. }\end{array}$} & \multicolumn{1}{|c|}{ Financial constraints } & $\begin{array}{c}\text { More } \\
\text { serious }\end{array}$ & \multicolumn{1}{c|}{ Serious } & \multicolumn{1}{c|}{$\begin{array}{c}\text { Less } \\
\text { serious }\end{array}$} & $\begin{array}{c}\text { Total } \\
\text { scores }\end{array}$ & Index \\
\cline { 2 - 7 } & \multicolumn{1}{c|}{$\%$} & \multicolumn{1}{c|}{$\%$} & \multicolumn{1}{c|}{$\%$} & - \\
\hline 1 & $\begin{array}{l}\text { Lack of adequate money for day-to- } \\
\text { day expenses }\end{array}$ & 5.00 & 62.00 & 33.00 & 172 & 57.33 \\
\hline 2 & $\begin{array}{l}\text { Insufficient financial assistance by } \\
\text { financial institutions }\end{array}$ & 4.00 & 17.00 & 79.00 & 125 & 41.66 \\
\hline 3 & $\begin{array}{l}\text { Problems of security and margin } \\
\text { money }\end{array}$ & 4.00 & 16.00 & 80.00 & 124 & 41.33 \\
\hline 4 & Tight repayment schedule & 0 & 3.00 & 97.00 & 103 & 34.33 \\
\hline 5 & Inadequate loan & 0 & 29.00 & 71.00 & 129 & 43.00 \\
\hline 6 & Delay in sanction of loan & 0 & 0 & 100 & 100 & 33.33 \\
\hline 7 & $\begin{array}{l}\text { Entire loan is not disbursed at a } \\
\text { time }\end{array}$ & 0 & 4.00 & 96.00 & 104 & 34.66 \\
\hline 8 & Less subsidy amount & 2.00 & 20.00 & 78.00 & 124 & 41.33 \\
\hline Composite index & & & & 40.87 \\
\hline
\end{tabular}

Lack of adequate money for dayto-day expenses was the most important constraint faced by the agripreneurs with index value of ' 57.33 , followed by insufficient financial assistance by financial institutions (41.66), problems of security \& margin money (41.33) and less subsidy amount (41.33).

Table 2

\section{Constraints Faced by Agripreneurs in Marketing}

\begin{tabular}{|c|l|r|r|r|c|c|}
\hline \multirow{2}{*}{ SI. No. } & \multirow{2}{*}{ Constraints in marketing } & $\begin{array}{c}\text { More } \\
\text { serious }\end{array}$ & Serious & $\begin{array}{c}\text { Less } \\
\text { serious }\end{array}$ & $\begin{array}{c}\text { Total } \\
\text { score }\end{array}$ & Index \\
\cline { 3 - 8 } & $\%$ & $\%$ & \multicolumn{1}{c|}{$\%$} & - & - \\
\hline 1 & Long distance to the market & 1.00 & 1.00 & 98.00 & 103 & 34.33 \\
\hline 2 & Lack of transportation facilities & 0 & 8.00 & 92.00 & 108 & 36.00 \\
\hline 3 & Lack of market information & 7.00 & 41.00 & 52.00 & 155 & 51.66 \\
\hline 4 & Low price for the produce & 10.00 & 26.00 & 64.00 & 146 & 48.66 \\
\hline 5 & Delay in payments & 2.00 & 7.00 & 91.00 & 111 & 37.00 \\
\hline \multicolumn{7}{|l}{ Composite index }
\end{tabular}


Lack of market information was the more serious constraint in marketing with index value '51.66', followed by low price for the produce (48.66), as perceived by the agripreneurs. As the respondents were not aware of the real time market information available in the related websites, they expressed the constraint on lack of market information as more serious. Exposure on the websites providing market information may overcome this constraint.

Table 3.

Constraints Faced by Agripreneurs in Production and Labour Management

$(n=100)$

\begin{tabular}{|l|l|c|c|c|c|c|}
\hline \multirow{2}{*}{$\begin{array}{c}\text { SI. } \\
\text { No. }\end{array}$} & $\begin{array}{c}\text { Constraints in Production and } \\
\text { Labour }\end{array}$ & $\begin{array}{c}\text { More } \\
\text { serious }\end{array}$ & Serious & $\begin{array}{c}\text { Less } \\
\text { serious }\end{array}$ & $\begin{array}{c}\text { Total } \\
\text { score }\end{array}$ & Index \\
\cline { 3 - 7 } & $\%$ & $\%$ & $\%$ & - & - \\
\hline 1 & Non availability of input materials & 9.00 & 67.00 & 24.00 & 185 & 61.66 \\
\hline 2 & High labour cost & 9.00 & 60.00 & 31.00 & 178 & 59.33 \\
\hline 3 & Non availability of skilled workers & 7.00 & 26.00 & 67.00 & 140 & 46.66 \\
\hline 4 & High cost of inputs & 4.00 & 11.00 & 85.00 & 119 & 39.66 \\
\hline \multicolumn{5}{l|l}{ Composite index }
\end{tabular}

It is seen from Table 3 that non availability of input materials (61.66) and high labour cost (59.33) were the major constraints, followed by non availability of skilled workers (46.66) and high cost of inputs (39.66) perceived by agripreneurs in production and

Table 4

Personal Constraints Faced by Agripreneurs

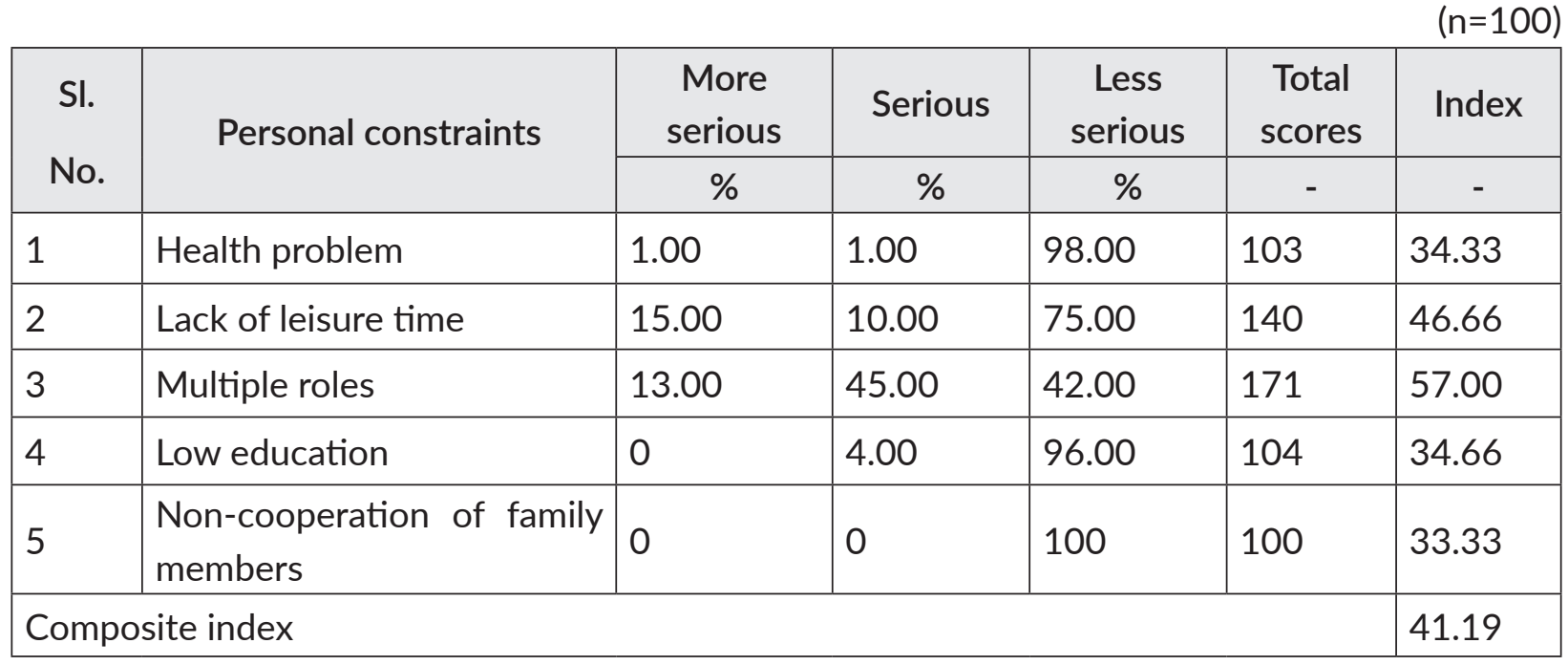


labour management. As the supply of most of the input materials are monopolized by few agencies, the agripreneurs were facing the shortage of supply of inputs during peak seasons and sudden price rise of the input materials.

It is observed from Table 4 that 'multiple roles' was the most important constraint faced by agripreneurs. Most of the respondents were engaged in other activities along with agribusiness as their subsidiary occupation. Therefore, they were not able to concentrate in agribusiness alone as they had to satisfy different responsibilities on various capacities. Non availability of required inputs, skilled labour and high cost of labour were the serious problems faced by agripreneurs.

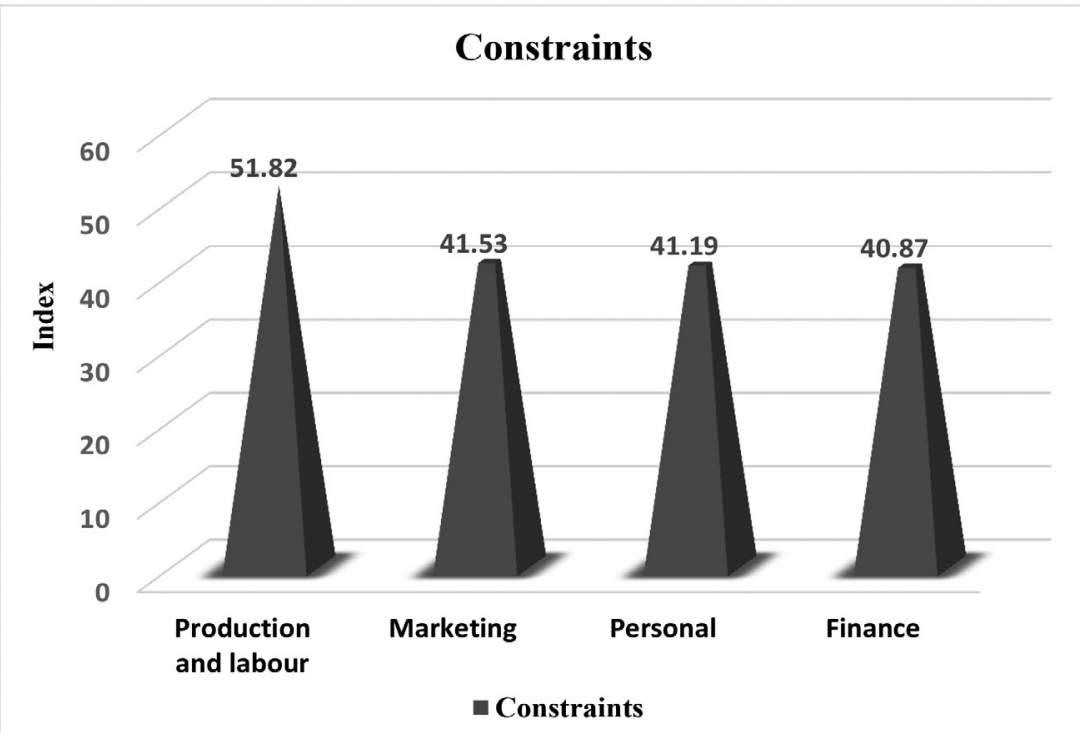

Figure 1. Constraints Faced by Agripreneurs

Production and labour constraints received the highest index value (51.82) among all constraints indicating that production and labour were the major constraints faced by agripreneurs, followed by marketing related constraints (41.53).

\section{CONCLUSION}

The study has clearly shown that the agripreneurs face production and labour management constraints predominantly followed by marketing related constraints. Non availability of required inputs, skilled labour and high cost of labour were the serious problems faced by agripreneurs. The extension centres of Kerala Agricultural University may prepare tailor made syllabus according to the specific demands, interests and requirements of a group of trainees. Training Need Assessment studies may be conducted before organizing the training programmes. Apart from imparting technical skills, the training modules should include the subject areas like, sources of funds available for starting agribusiness, services of financial institutions, details of government schemes available for agripreneurs, pro-active managerial skills and soft skills required for managing agribusiness, judicious use of available resources, maintenance of records, sharing responsibilities with fellow members, ways of enhancing entrepreneurial competencies, access to real time market information using ICT tools and 
6078

available technologies on mechanizing agrienterprises.

\section{REFERENCES}

Aiswarya, S. (2016). Emotional intelligence among the employees of ESAF Microfinance and Investment (P) Ltd. Unpublished MBA(ABM) thesis, Kerala Agricultural University, Thrissur, 88p.
Nagalakshmi, T., \& Sudhakar, A. (2013). Agripreneurs: A Case Study of Dharmapuri Farmers. International Journal of Science and Research. 2(8): 208-214.

Uplaonkar, S. S. \& Biradar, S. S. (2015). Development of agriculture in India through agripreneurs. International Journal of Applied Research. 1(9): 1063-1066. 